\title{
13 An evaluation of Pentecostal Churches as agents of sustainable development in Africa
}

\author{
The case of the Church of Pentecost
}

\author{
Emmanuel Kwesi Anim
}

\section{Introduction}

The term development comes with some nuances, it is sometimes loaded with past meanings, some of which are not positive. Some think of development as material change or social change in the material world. Others understand the term to mean westernisation or modernisation and the underlying factor is associated with having more things (Myers 1999, 3). Myers talks of transformational development to mean an action or process whereby one seeks positive change in the whole of human life materially, socially and spiritually, while the adjective transformational is a reminder that human progress is not inevitable but requires hard work and depends on the choices that we make. It is against this background that I see that sustainable development provides us with a more detailed and comprehensive framework for addressing the human condition. We understand sustainable development as economic development that is conducted without depletion of the natural resources. In other words when we talk of sustainable development, we mean transformational and responsible development. It is a situation where development meets the needs of the present without compromising or limiting the ability of future generations to meet their own needs.

Recent discussions have focused on the Sustainable Development Goals (SDGs). At the core of the SDGs is a fight against extreme poverty, inequality and injustice and to address the challenge of climate change. That the set goals are interconnected is a stark reminder that we live in a global village where artificial boundaries no longer define our sense of identity and common destiny. The success of one goal often requires tackling issues more commonly associated with another. This understanding inspires a sense of collective responsibility, the spirit of partnership and pragmatism in the working together of all stakeholders. Recent developments in science and technology and frequent movements of information, people and other resources across boarders means that new emphasis should be placed on our common and shared humanity

\section{Values-based development and religious communities}

It is said that over 80 per cent of the global population has some affiliation with religious communities (BMZ 2016, 8). Religious communities have often 
contributed to the provision of services such as medical, education, agriculture and other essential services like water to people across the world and particularly in Africa. Many NGOs such as the World Vision and Tear Fund make considerable contributions to the individual and community in relief and development, as do other faith-based institutions and organisations. It has been observed that in some countries in sub-Saharan Africa, religious communities provide more than 50 per cent of all social services (BMZ 2016, 8). Religion brings people together; however, it has the potential to disrupt the peace and stability of society. Therefore, the need to strengthen the potential that religion can bring to society cannot be overemphasised. Similarly, creating appropriate awareness and tolerance among religious groups can strengthen the potential that religion can offer for development, particularly in Africa.

In his introduction to Religious Communities as Partners for Development Cooperation (BMZ 2016) Gerd Müller, German Federal Minister for Economic Cooperation and Development, highlights some important virtues that flow out of religious communities. Faith communities have often played significant roles in helping the poor and vulnerable and the marginalised in society. The act of compassion in many cases defines religious communities. As we hear of Mother Theresa of Calcutta so we can also talk of Rev. Fr Andrew Campbell, the Irish Catholic priest who has been working in Ghana for many years and founder of the Weija Leprosarium in Accra, where many lepers, some of whom have been abandoned by their families, are given a home, food and medical care. 'A values-based development policy means that we take the contribution of religion seriously, engage with religious actors and seek to find common answers to hunger, misery and injustice' (BMZ 2016, 5). It is an admissible fact that it would be nearly impossible to achieve the Agenda 2030 unless the religious communities are active partners in this process. This is also the case knowing that 'religion is a defining factor for most people's view of the world, their lifestyles and their civic engagements. It continues to have a strong influence on political and social life' (BMZ 2016, 11-12).

In many developing countries, people have more confidence in religious leaders than in their political leaders. As a result, religious institutions are often the first place people turn to in an emergency. Religion can strengthen the resilience of individuals and entire societies because it offers explanations and rituals that help people deal with loss, suffering, failure and disaster.

Religion can give people a sense of identity and bring people together in the same way that it can also be used to exclude people. Religion can also be exploited in order to safeguard one's position of power, suppress critical voices and avoid democratic reforms.

(BMZ 2016, 12)

\section{The myth of development in Africa}

The pursuits of independence for Africa were marked by two assumptions. First, that the land was endowed with abundant natural resources to sustain its people; 
and, second, the leaders were capable of managing their own resources for the benefit of the African people. This may be argued against the backdrop of enormous natural and mineral resources available on the continent. But such hope and aspiration soon disappeared as African states came to be described as 'vampire states' where the state, which was meant to be the 'mechanism for the pursuit of public benefit' became 'an instrument of exploitation, managed purely in the interest of those who held power' (Gifford 1998, 12). This analysis, however, does not lend itself to other external factors such as imbalances in international trade often in favour of western nations.

Most African independence coincided with the period of the Cold War - the battle of ideologies of politics and development. Many African leaders such as Kwame Nkrumah of Ghana, Kenneth Kaunda of Zambia, Jomo Kenyatta of Kenya, Haile Sellassie of Ethiopia, Julius Nyereyere of Tanzania and Ahmed Sékou Touré of Guinea among others, sought to fashion an African unity, which would consolidate Africa's resources and compete with the rest of the world. Thus, Kwame Nkrumah, the first prime minister of Ghana, on 6 March 1957 when Ghana attained independence remarked that 'the independence of Ghana is meaningless unless it is linked to the total liberation of the whole African continent'. However, the lack of national unity, social controls and organisational capacities on the part of most African states undermined sustainable growth of their development.

Many post-independence African countries tied their politics and economies to their colonial roots mainly in the West in different variations, while others looked to the communist East for political and economic ideologies. This orientation meant that independent African states indirectly joined the battle of the Cold War. Between the 1970s and early 1980s, African leaders who looked to the East and were inspired by Marxist ideology advocated a revolution to overthrow both the imperial apparatus and the African elite in government who were considered parasitic and corrupt. Military coups and dictatorship became the order of the day and it turned out to be the means by which the poor enriched themselves. For example, the most popular Nkrumah government in Ghana was overthrown in a military coup in 1966, since it was authoritarian, corrupt and had no regard for the rule of law. Nkrumah was seen to have embraced socialist ideals and a personality cult was built around him. This situation became enough justification for his removal from office by the military. Gifford observes that, 'the military handed over to Kofi Busia's Second Republic (1969-1972), which ended with another coup. During the ensuing years of rule by a corrupt Military Council, particularly under General Ignatius Acheampong (1972-1978), Ghana bordered on collapse' (2004, 2). It is disturbing to note that the Acheampong's military government was also toppled in yet another military coup on 4 June 1979, led by Flight-Lieutenant John Jerry Rawlings who also claimed corruption of the military elite as justification for his actions. Upon assumption of power, Armed Forces Revolutionary Council led by Jerry Rawlings executed in public eight senior military officers including three former heads of state on 16 and 26 of June 1979. It was observed that 'the popular 
mood included a good deal of envy and anger against those who were thought to have enriched themselves at the expense of the masses' (Gifford 2004, 1).

By the close of the 1980s, and after the fall of communism, most African leaders were beginning to change their perspective and turned to the West. Here, the International Monetary Fund (IMF) and the World Bank became significant. Various attempts were made to address Africa's development needs through different economic models or theories.

Gifford (1998) aptly explains that around the time of Africa's independence in the 1960s, modernisation theory was thought to hold the answer to Africa's economic needs as it would transform Third World countries into participative, pluralist and democratic regimes. The state and the ruling elite were considered to be the primary agent of political and economic development and the principal bearers of modernisation. Development was conceived as centre-outward and top downwards process. This model was inspired by a similar one which had been experimented in Latin America in the 1950s. The euphoria of modernisation theory was short-lived when it was observed that modernising elites were parasitic and serving their own and foreign interests and not that of their people (Gifford 1998). World trade was perpetuating structures of underdevelopment and not removing them. Modernisation is used to explain the socioeconomic and political process that a nation goes through when it transforms from a traditional society to a modern one. The theory works on the assumption that as nations develop, economic development and social change would lead to democracy. This theory is often attributed to American social scientists in the 1950s based upon Rostow's stages of development. Here it is believed that social mobilisation would cause individuals and societal groups to change their aspirations which would eventually lead to economic development (Rostow 1990). The modernisation model was subsequently replaced by the dependency model in the 1970s. Dependency theory, which became popular in the 1960s is based on a Marxists analysis of the world, which sees globalisation in its manifestation of market capitalism as perpetuating exploitation of cheap labour and resources in the developing countries in return for obsolete technologies of the West. The dependency theory argues for an 'inward-looking' approach to development and an increased role for the state in terms of imposing restrictions to trade and promoting nationalisation of key industries. However, the inability of African states to properly manage the economic affairs of the nations as a result of endemic corruption, had made this economic model unsuccessful.

The 1980s saw the introduction of the Economic Recovery Programme (ERP) which aimed at resuscitating Africa's economy by reducing inflation to achieve equilibrium. The process sought to promote economic growth and export recovery through a realignment of incentives towards productive activities. However, the dependency model was seen as even more disruptive than the modernisation model. It was believed that at the time of independence, power had been given to the wrong people. Africa's corrupt elite and their selfseeking policies were responsible for the problems in Africa. 
The new realism model was introduced in the latter part of the 1990s. The theory behind this model was a call for structural adjustment in the economies of the Third World countries. The idea was promoted mainly by the World Bank, the IMF and American policy-oriented academics. It was the theory behind the New Realism that introduced the Structural Adjustment Programme (SAP). The SAP required cuts in government expenditure, and this meant in practice, the withdrawal of government subsidies from health services, agriculture, education and utility services such as electricity and water supply (Gifford 1998).

The government of Ghana in 1995 prepared a long-term national development framework with the view of accelerating social and economic development within a reasonable period of 25 years. This was known as 'Vision 2020', and would be rolled out in phases of five years.

The basic assumption underlying the preparation of this plan was that a partial foundation had been established by the ERP for the long-term economic and social development; but the foundation needed to be strengthened to ensure more rapid growth in the future to enable Ghana to join the ranks of middle-income countries.

(Asante and Owusu 2013, 3)

In all these theories and related programmes, the assumption was that productivity would increase through capacity building of human resources. Agriculture and industry would generate wealth which would eventually trickle down to the masses. But these laudable ideas were only to remain a dream. In 2002, Ghana had to apply for the Heavily Indebted Poor Countries (HIPC) initiative in order to survive rather difficult macroeconomic conditions. The inflation rate was 'about 40.5 per cent (instead of the 8 per cent anticipated in 2000), and exchange rate depreciation of about 49.8 per cent [against the US dollar] (instead of the 6 per cent targeted in 2000)' (Asante and Owusu 2013, 6). The HIPC initiative, although humiliating for a sovereign nation, as its credit rating was downgraded, was also an attempt by government to reduce its debt burden and have easy access to more external resources for accelerated poverty reduction. HIPC was administered by the World Bank and the IMF. For a good analysis of post-independence Africa's social, economic and political development, see Gifford (1998, 1-56), also Asante and Owusu (2013, 1-24).

Various reasons may account for the reason why development models fail in Africa, and some of these tend to be ignored by local governments and western policymakers on Africa's economic development. Here, I would like to consider the key ones. The first is the primal worldview and mentalities towards wealth acquisition. Our best analysis comes from G. M. Foster. In his book, Traditional Societies and Technological Change, Foster argues that 'animistic" ${ }^{\text {' }}$ worldview, determines that resources are limited just like a piece of cake. Therefore, by implication, the size of one's wealth is at the expense of another who may have very little or nothing. Foster explains this as 'the concept of the limited good'. In response, the rich sometimes conceal their wealth for 
fear of being accused of selfishness and using malicious means such as witchcraft in acquiring wealth. As a result, those who are wealthy or have the money to start projects become reluctant to do so particularly within their immediate communities or hometowns.

The next factor is ritual taboos and land tenure systems. Sometimes development projects are put on hold because local people believe that the gods may not be happy with them. For example, there have been cases where road constructions to important places for economic reasons had to be abandoned. Some days are classified as 'Sabbath' and would be a taboo if people went to the farm, sea or rivers on such days for economic activity. In some situations, a six-week traditional ban on noise making by the local chiefs prior to major annual festivals such as Odwira and Homowo celebrated by some Akan groups and the Gas, respectively, could mean that no social or economic activity which involves noise making could go on. These traditional customs have brought conflicts between social groups such as the church and local chiefs and their people leading to adverse effect on economic activities and development. For example, in the last two decades there have been several confrontations between the Ga traditional council and some Pentecostal and Charismatic Churches in the Greater Accra Region, leading to the destruction of church musical instruments and injuring some church members. In seeking a lasting solution, the Accra Metropolitan Assemblies issued the following directives:

During the period of the ban, the usual form of worship should be confined to the premises of churches/mosques and noise levels be minimized to the barest limits possible ... the positioning of loudspeakers outside the premises of churches, mosques and pubs are banned. Roadside evangelists are to cease their activities during this period. Apart from an identifiable task force which consists of AMA personnel, the Police Service and Representatives from the Traditional Councils with tags, no other person or group of persons should be seen or found enforcing the abatement of noise in the metropolis. ${ }^{2}$

\section{Frequent military coups and dictatorship}

Frequent military interventions have proved more of a liability than anything else in dealing with Africa's development problems. Very often, the military has been more corrupt and had to spend a great deal of state money in arms to keep its position in power. Ghana, for example, from the time of independence from the British in 1957 to 1992, had witnessed not less than five military interventions in government and many other failed ones. The situation is not particularly different in Nigeria, Liberia, Sierra Leone and Burkina Faso to name but a few. Once a country slides into military regime, many investors particularly those from the West withdraw their funding and so much of state funds are used to acquire arms at the expense of productive economic ventures and social infrastructure such as schools and hospitals. 


\section{Nepotism, bribery and corruption}

It is observed that African states were from the beginning essentially an agency for control and extraction of resources (Gifford 1998, 4). The partitioning of Africa into numerous states along colonial lines was perceived as an instrument of the West to take control of African resources for the benefit of the western nations (Davidson 2005). Africans therefore saw the statement machinery as a tool of the colonial master and therefore saw no reason to be committed to the public institutions. The local parlance in Ghana is that, 'you don't carry the government work on your shoulders, you drag it on the floor' meaning one should not toil for the work of the government or the state. This makes African states quite different from the western states in terms of shared values between state and society. Gifford argues that

colonial administrations were both centralized and authoritarian. Just as important, the rulers manifested a sense of superiority over those they ruled, and power was experienced as coming from above rather than below. Thus the ruled developed a sense of the state as an alien institution, to be feared but also to be deceived and exploited, since it existed on a plane above the people whom it governed, beyond any change of control.

In western societies, power is exercised through legally defined structures for a publicly acknowledged aim. Officials who exercise the powers of office treat other individuals impersonally, according to the criteria which the structures demand. Successive officials would act the same, and respect the rules of the office. This has been the way of running complex modern state. In many respects, one may argue that African states have performed badly in adopting this rational-legal mode of organising a state and shared resources. African governments and other public leaders tend to run the state on a system of kinship and loyalty, which encourages cronyism and nepotism (Gifford 1998, 5). This is the means by which leaders consolidate their grip on power and the loyal subordinates feel secure and protected and resources are channelled between these lines.

Following Max Weber (1976), Gifford aptly observes that this system is based on the kind of authority a father has over his children. Those on the lower ranks of business are not subordinate officials with well-defined powers and functions but retainers whose position depends on a leader to whom they owe allegiance (Gifford 1998, 5). For many Africans, having the privilege to serve in a public office is also a privilege to maximise one's personal fortunes at the expense of the shared resources of the state.

If corruption is defined as the use of public office to achieve private goals, then corruption simply does not make sense in many societies in Africa where there is no separation between public and private lives in peoples' minds, and personal and official lines of duty. Public office is often seen as the route to 
personal wealth and power as the popular African maxim goes, 'the goat eats where it is tethered'. This is the reality that confronts many African states and any credible analysis of African development cannot ignore these unfortunate situations.

\section{Ghana in context}

Ghana has enjoyed a relatively stable society since the country returned to constitutional rule in 1992. However, persistent trade imbalance, high inflation and corruption have bedevilled the nation in recent years. The hold-up of the results of the 2012 general elections which was contested in court by the main opposition party the National Patriotic Party (NPP), went on for the best part of eight months (December 2012-August 2013). The situation contributed to a major depreciation of the cedi against major trading currencies as investors began to move their investment to other neighbouring countries. The economic situation was also aggravated by a prolonged shortage of electrical power to feed the industries and other businesses. This also meant that there were less resources available to government to undertake development projects and to support education and health services. The National Health Insurance, introduced by the previous government led by Mr John Agyekum Kuffour was at risk of collapsing. Inadequate medicine in the hospitals forced government to withdraw allowances for teachers and nurses in training which had existed for several years.

It has recently been reported that malaria is the leading cause of deaths in Ghana and on average three children die every day as a result of malaria, while $\$ 6.6$ million is lost to loss of productive hours as a result of malaria and related illnesses. The recent illegal mining known as 'galamsey' continues to destroy the nation's major rivers which provide drinking water as well as support aquatic life and maintain balance in the ecology. A recent report indicated over $\$ 6$ million was lost to the government in the year 2017 as a result of illegal mining which is now being championed by Chinese immigrants in the country. The government's decision to ban all forms of small scale and illegal mining has not been easy to implement as pockets of persons and companies continue with the practice underground. However, there is every reason to hope for the better and the recent change in government with an unprecedented majority in favour of the NPP government opens new opportunities for development as the new government has activated its manifesto to provide free education to all citizens up to the secondary level. Allowances for trainee nurses ${ }^{3}$ have been restored and attempts are ongoing to revive the National Health Insurance Scheme which is meant to make basic healthcare affordable to all citizens. ${ }^{4}$

There has been relative stability in the value of the cedi and interest rates from the Central Bank have also reduced but this has not translated to the benefit of the ordinary citizen as the commercial banks continue to charge exorbitant interest on loans, making it difficult for local businesses to thrive. There is the attempt on the part of government to implement a policy of one factory 
for each of the 254 administrative districts in the country and provision of dams for rural areas whose main economic activity is agriculture. The appointment of the President of Ghana, Nana Addo Danquah Akuffo-Addo, together with the Prime Minister, Erna Solberg of Norway, as co-chair of the Sustainable Development Goals Advocates in April 2017 is an added inspiration to the new government in its attempt to achieve both political and economic success.

\section{Pentecostals and social action}

Early Christian thinking on mission and development was of a divisive nature. Some Evangelical Christians and particularly Pentecostals did not support the view that the church should put time and resources into development programmes or social action but rather focus on its primary task of evangelism and soul winning. It becomes obvious that 'the modern assumption that the spiritual and the material were unrelated areas of life had infected Christian mission thinking' (Myers 1999, 2). Myers argues that this idea goes back to a western worldview:

I will struggle to overcome problems presented by the persistent and insistent belief in the West that the spiritual and physical domains of life are separate and unrelated. This assumption has invaded and controlled almost every area of intellectual inquiry, including development theory and practice as well as much Christian theology. I will seek an understanding of development in which physical, social and spiritual developments are seamlessly interrelated.

$(1999,1)$

Over the past three decades, Pentecostalism has become the focus of considerable historical and sociological research with scholars writing on a wide range of themes in the development of the Pentecostal/Charismatic movement. Pentecostalism is a renewal movement within Protestant Christianity that places emphasis on a direct personal experience of God through baptism with the Holy Spirit, with evidence of speaking in tongues or glossolalia. Many scholars trace the origins of Classical Pentecostalism to the early part of the twentieth century in 1901, with Charles Parham as the leader. The initial experience was recorded at the Bethel Bible School in Topeka, Kansas in the United States of America. However, it was the ministry of Joseph Seymour, a student of Parham, and the revival that took place in 1906 at Azuza Street, which brought classical Pentecostalism to global prominence (Hollenweger 1972). A similar movement known as Neo-Pentecostals or Charismatics emerged in the 1950s where tongues speaking was not always regarded as essential evidence of baptism with the Holy Spirit. In both movements there is a strong link between baptism in the Spirit and evangelisation.

In 1970, David Barrett boldly predicted that the number of Christians in Africa would reach 350 million by the year 2000. This was from a mere 


\section{Emmanuel Kwesi Anim}

10 million in 1910 (Barrett 1970, 39-54). In 2001, Barrett published the second edition of his seminal World Christian Encyclopedia, and estimates the actual Christian population to be 360 million, which was more than he had previously predicted. His classic reference book further illuminates the changing demography of modern Christianity and the massive shift of the faith's centre of gravity from the West to the southern continents of Asia, Africa and Latin America (Barrett et al. 2001). And for the first time in Christian history, we were told that at the beginning of 2018, there are about 631 million Christians in Africa ahead of Latin America, Asia and Europe. This makes Africa the continent with the majority of Christians in the world (Johnson et al. 2018, 4). What is significant for this study is Jenkins's observation that the stupendous growth of the church in Africa, Asia and Latin America lies principally in the Pentecostal/Charismatic strand of Christianity, which are far more traditional, morally conservative, evangelical and apocalyptic than their northern counterparts (Jenkins 2007, 7-8).

In spite of the impressive statistics about the growth of the church in Africa and particularly among the Pentecostals, there remain a number of issues that need to be explored and answers found to the question such as why the church in Africa does not have a corresponding positive effect on the social and economic lives of the people? It is estimated that Africa continues to have a high number of its citizens fleeing the continent as refugees to seek greener pastures in the West.

The office of the United Nations High Commissioner for Refugees (UNHCR) report 'Global Trends: Forced Displacement in 2016' indicates that nearly 66 million people have been displaced around the world as refugees (UNHCR 2017, 2). Nearly one-quarter of the refugees are in Africa. Conflicts in South Sudan, Sudan, Central African Republic, Somalia and Nigeria have driven nearly 15 million Africans from their homes (UNHCR 2017, 6).

African refugees move in all directions. Some venture to neighbouring African countries where economic and political lives are deemed to be better. According to the UNHCR report, the African countries with the highest number of refugees include Uganda (940,835), Ethiopia $(791,681)$ Kenya $(451,099)$, Chad $(391,251)$, Cameroon $(375,415)$ and South Sudan $(262,560)$ (2016, 60-63).

Other refugees and migrants risk the treacherous routes to North Africa en route to Europe and Asia. In the process many lose their lives, while others are taken into forced labour by their captors. Many Ghanaian women who journeyed to Saudi Arabia in search of a better life ended up as sex slaves and suffered horribly. As refugees and illegal immigrants, such persons are vulnerable and barely have any access to judicial processes and human rights protection. In Ghana, the Ministry of Foreign Affairs recently issued a ban on the travel of Ghanaian women to Saudi Arabia in search of jobs (Daily Graphic 2017, 20).

\section{A new era of Pentecostal missiology and development}

The last decade has seen a new development in the missionary thinking of many Pentecostal and Charismatic Churches in Africa. About two decades ago, these 
churches were principally associated with the American Faith Gospel and prosperity teaching (Anim 2003; Gifford 1998). It has become abundantly clear that Pentecostals are not only making their mark in the social and economic space of the nations but also becoming politically influential. The current President of the Republic of Ghana, Nana Akufo-Addo, openly declared that the immediatepast Chairman of the Church of Pentecost, Apostle Professor Opoku Onyinah, is his spiritual adviser. Bishop Charles Agyin-Asare of the Perez Chapel International was known to be the spiritual adviser to the late President Atta-Mills, while Archbishop Nicholas Duncan-Williams of the Christian Action Faith Ministries was known to have a close association with the ex-President Jerry John Rawlings of the PNDC government. It is without doubt that the Pentecostal and Charismatic Churches have a very large following in Ghana.

\section{The Church of Pentecost and sustainable development}

The Church of Pentecost (CoP) was founded in 1962 by an Irish missionary, Rev. James McKeown. McKeown's history in Ghana stretches all the way back to 1937, when he first arrived in the Gold Coast at the invitation of the Faith Tabernacle Church, led by Peter Newman Anim. For a good study of the history of the CoP, see Leonard (1989) and Onyinah (2016, 12-35). By the time James McKeown retired from active service as a missionary-pastor and returned home to Northern Ireland in 1984, the CoP was well established in Ghana with additional branches in Côte d'Ivoire, Togo, Benin, Burkina Faso, Sierra Leone, Benin, Nigeria and Liberia.

The CoP currently has a worldwide membership of about 3,037,068 represented in 99 countries across the globe. The CoP, with the current membership of about 2,566,818, constitutes about 9 per cent of the total population of Ghana.

The significance of the CoP in the social and economic development of Ghana is best summed up in the words of the Vice President of the Republic of Ghana, Mahamudu Bawumia, who hailed the church as a model and inspiration for Ghana's quest for social and economic development. Bawumia's point was that the $\mathrm{CoP}$ has proved through its effective organisational structure and infrastructure that it was possible for Ghana to develop without relying on external aid. The $\mathrm{CoP}$ is on record as having used indigenous resources to impact their communities without reliance on foreign aid. In a paper presented by the General Secretary of the CoP, Apostle Nana Yaw Kumi-Larbi, at a function organised by the government, Kumi-Larbi made the point that 'with the right kind of leadership and prudent management of resources, the vision of Ghana beyond aid is not only realistic but achievable'. The CoP has established 84 basic schools, eight health institutions, two senior high schools, three vocational institutes, a university college and a theological seminary all from its own internal resources.

The modern Pentecostal Convention Centre (PCC), which has the capacity of a 5,000-seater auditorium, a 3,000-seater auditorium as well as a 500-and 
200 -seater auditorium and facility for 2,500 en suite accommodation for various conferences were constructed within the record time of about four years. The Pentecost Theological Seminary and a modern police station with staff accommodation were all constructed by the church within a six-year period at a total cost of about GHS169.2 million or approximately US $\$ 37.6$ million. The PCC which is situated on a 250-acre land has played an important role in the regeneration of the Gomoa Fetteh community which has since seen significant improvement in the immediate local economy.

\section{'Pentecost model' and value for money conference}

The CoP has been noted as a leading player in the construction of progressive Pentecostalism. Following James Forbes's analysis of 'Progressive Pentecostalism', David Daniels observes that since 1979, the CoP has 'widened its scope of social ministry as it improves the lives of the marginalised in society, expanded its theology of social engagement, embraced the four traditions of philanthropy, and played a pivotal role in the strengthening of civil society as it has promoted social development and fostered civic trust within Ghana' (Daniels III 2018, 50). Daniels's assertion is underscored by the invitation of the government of Ghana for the CoP to explain the nature and approach of its social and economic projects. Presenting a paper entitled 'Value for Money in the Construction of School: A Case Study of the Church of Pentecost', the General Secretary of the church, Apostle Alexander Nana Yaw Kumi-Larbi, outlines some cost-effective means adopted by the church in constructing educational facilities.

Apostle Kumi-Larbi explains that the CoP follows five policy guidelines, namely: procurement-related factors, design value/engineering and technical post-contract supervision, cost management factors, audit monitoring and evaluation of projects and strong internal organisational culture. Kumi-Larbi who is also a civil engineer by profession explains that with the exception of minor maintenance works, all new works are subjected to competitive tendering with the high potential of cost savings. By procuring construction materials and paying for labour together with strict adherence to policies on procurement procedures during tendering and by ensuring promptness in the procurement process for the delivery of infrastructural projects, the church is able to reduce the overall cost of its infrastructural project by 15 to 25 per cent. The CoP also has other control measures in place such as the audit, monitoring and evaluation (AME) unit at the headquarters, which provide checks and balances for works supervised by the consultants and also provide controls for projects executed. The audit division reviews financial submission, the monitoring division provides quality control services, while the evaluation division is responsible for providing value engineering services.

The Value for Money Conference was held in Accra on 25 June 2018, and chaired by the vice president of Ghana. The conference was attended by government officials and leaders from the private business sector including Hon. 
Yaw Osafo Maafo (Senior Minister), Hon. Ken Ofori-Atta (Minister of Finance), Tony Debre (Head of Projects, Ghana Education Trust Fund), Mr Rajiv Aggarwal (World Bank) and Robert Kuzoe (MTN Ghana).

\section{Evaluation}

Kwame Bediako draws attention to a framework which can better help to evaluate understanding of the mission of the church and particularly in reference to both its spiritual and moral impacts. In his article, 'What Is the Gospel' (1970), Bediako makes it clear that the church has often misunderstood its mandate of the Great Commission. He observes, the Gospel of salvation which comes through Jesus Christ has more to do with the nations and the things which make nations, than it has often assumed. He explains that the Great Commission, therefore

is about the disciplining of the nations, the conversion of the things that make people into nations - the shared process of thinking, the shared and common attitudes, worldviews, perspectives, languages, cultural and social and economic habits of thought and behaviour and practice - all those things and the lives of the people in whom those things find expression.

(Bediako 1997, 3)

Thus, Bediako goes on to explain that we have often become so used to regarding the Gospel as concerned with individuals that we are much less alert to its

fundamental relationship to those elements and dimensions of our human existence which designate as culture - language, social values, cultural norms, religion, political organization, ethnic identity, technology, arts and craft and economic activity.

In this regard, the tendency has been to reduce the Gospel to a category we regard as purely spiritual and has no reference to our culture or way of life. The danger here, Bediako observes, is that Christianity at best becomes an overlay of already existing worldview and mentalities, 'our old habits and attitudes and fears, of some regulations and traditions and solutions which do not answer to our needs' (1997, 3). Thus, mission and evangelisation is about transformation of people and cultures in the light of God's word. While in the past most Pentecostals have frowned at social action and development issues, it is the case that this tendency is fast changing in favour of a more comprehensive and holistic approach to Christian mission. In 1980, the CoP established the Pentecost Welfare Association (PENTWAS), which subsequently became the Pentecost Social Services (PENSOS) in 2000. PENSOS was given a directorate and a mandate to provide education, health facilities, relief services and address social needs among its members and the communities in which the church operates. 
The CoP also provides funding for the Ghana AIDS Commission and is actively involved in the campaign to forestall environmental degradation and to keep the communities clean. On 22 November 2018, the CoP launched a major environmental campaign in collaboration with the Zoomline waste management company in Accra. The ceremony, which received extensive media attention was attended by Ministers of State and a cross section of the Ghanaian public and church members. The theme for the environmental care campaign was 'My Environment, My Responsibility'. In this campaign, attention was given to sanitation and environmental cleanliness, land and water pollution, air pollution and waste management. As a church initiative, the Church of Pentecost has called on all its members and particularly the ministers throughout the country and in all other nations where the church has branches to spearhead this vision. The church also uses its private television network, the Pent TV, to discuss relevant issues on environmental care and educate the wider public on the need for environmental preservation as a divine responsibility to be stewards of God's creation. However, a lot more needs to be done as what can be said of the Church of Pentecost cannot be said of many other Pentecostal and Charismatic Churches in Ghana, some of whose activities have recently been called into question. There are several accusations of some African Initiated Churches (AICs) such as the prophetic ministries or churches whose leaders are known to take undue advantage of their congregation and extort monies from them without any accountability. This situation has necessitated a debate as to whether the churches in Ghana should be made to pay taxes to the state in view of the perception that the churches have now become business ventures and avenues for economic exploitation and abuse of power.

\section{Conclusion}

During his official visit to Ghana in July 2009, President Obama of the United States of America made the point in his address to Parliament that 'Africa doesn't need strong men, it needs strong institutions' that work. This was part of his speech made to the Parliament. Sustainable development should always take into consideration the socioeconomic structure of the community. In the same vein, development models in Africa should be bottom-up rather than topbottom. It should seek to empower the masses through education, healthcare and small-scale enterprises and the religious community has an important part to play.

We have looked at two distinct but related issues in African experience. The conflicts in Africa also have socioeconomic consequences which impact negatively on national and individual development. Our analysis has shown that the situation is quite complex. The legacy of colonialism continues to be felt even in modern African states. The traditional African worldview and mentality hold sway when it comes to work ethics.

The issue of kinship ties, nepotism, ritual taboos and corruption are critical to Africa's development and need to be addressed. Here, the Christian mission 
can make a contribution by helping people to see beyond specific ties to the family and personal interest. The late Professor Kofi Abrefa Busia, a sociologist and lay preacher of the Methodist Church Ghana, and former Prime Minister of the Republic of Ghana, observes thus:

For the conversion to the Christian faith to be more than superficial, the Christian church must come to grips with traditional beliefs and practices, and with the worldview that these beliefs and practices imply. It would be unreal not to recognize the fact that many church members are influenced in their conduct by traditional beliefs and practices, and by the traditional interpretation of the universe. The new convert is poised between two worlds: the old traditions and customs he is striving to leave behind, the new beliefs and practices to which he is still a stranger. The Church would help him better, if she understood the former, while she spoke with authority about the latter.

(Busia 1955, 4)

It is gratifying to note that in the last two decades, the $\mathrm{CoP}$ has sought to engage the worldview and culture of the people and confront the ills of society while addressing the spiritual needs of its members. As Pentecostals debate globally whether social ministry may complement evangelism or undermine it, the CoP has wholeheartedly embraced an understanding of holistic ministry that combines evangelism and social action or intervention without apology (Daniels III 2018, 51). Peace and development may not necessarily be the absence of war but the presence of Christ who fulfils the dreams of the poor and the destitute (Luke 4:16-18) and calls into account the rich and the powerful. This message should not be told only in the church but to the wider society. We maintain that this is the path some Pentecostal Churches in Africa have chosen and the CoP remains one of the best models worthy of investigation.

\section{Notes}

1 I prefer the term, 'primal' to primitive as the latter carries a derogative impression.

2 Accra Metropolitan Assembly, press release, Thursday 10 May 2018; Ref. A.025/6/25, 'Ban on Drumming and Noise Making'. Signed by Gilbert Nii Ankrah, Head of Public Relations for the Metropolitan Chief Executive. Further information available at www.ghanaweb.com. Dailyguideafrica.com

3 'Nurses Training Allowances Restored', www.ghana.gov.gh/imdex.php/news/4064restoration-of-nursing-training-allwances-have-come-true-president. Accessed 7 April 2019. About 58,000 health training nurses and midwives whose monthly allowance of about $\$ 80$ was stopped by the previous administration were restored in 2018 by the Akuffo-Addo government.

4 See 'GHC1.2bn NHIS debt inherited from NDC fully paid off', https://mobile.ghanaweb. com/GhanaHope Page/NewsArchives/GHC1-2bn-NHIS-debt-inherited-from-NDCfully-paid-off-Bawumia-699436. GhanaWeb, Health News of Fri, 9 November 2018, The amount is an equivalent of about $\$ 300$ million. Also reported on Myjoyonlne.com, 21 April 2018.

5 Barack Obama, reported on www.sundaytimes.lk/090712/International. Accessed 7 April 2019. 


\section{References}

Anim, Emmanuel. 2003. 'Who Wants to be a Millionaire? An Analysis of Prosperity Teaching in the Charismatic Ministries (Churches) of Ghana and Its Wider Impact.' Ph.D. thesis, All Nations Christian College, The Open University, UK.

Asante, Felix A., and Kenneth Owusu. 2013. 'Overview of Ghana's Development: Policies and Options.' In Policies and Options for Ghana's Economic Development, edited by Kodwo Ewusi. Accra: Institute of Statistical, Social and Economic Research, University of Ghana.

Barrett, David B. 1970. 'AD 2000: 350 Million Christians in Africa.' International Review of Mission 59: 39-54.

Barrett, David B., George Thomas Kurian, and Todd M. Johnson, eds. 2001. World Christian Encyclopedia. 2nd edition. New York: Oxford University Press.

Bediako, Kwame. 1997. 'What is the Gospel?', Transformation 14, no. 1: 1-4.

BMZ. 2016. Religious Communities as Partners for Development Cooperation. Berlin: Bundesministerium für wirtschaftliche Zusammenarbeit und Entwicklung.

Busia, K. A. 1955. 'The African World View.' In Christianity and African Culture: The Proceedings of a Conference Held at Accra, Gold Coast, May 2nd-6th, 1955. Accra: Christian Council of the Gold Coast.

Daniels III, David D. 2018. 'Progressive Pentecostalism, Pentecostal Philanthropy: The Church of Pentecost.' In African Pentecostal Missions Maturing: Essays in Honor of Apostle Opoku Onyinah, edited by Elorm Donkor, and Clifton R. Clarke. Eugene, OR: Pickwick Publications.

Davidson, Basil. 2005. The Black Man's Burden: Africa and the Curse of the Nation-State. Ibadan: Spectrum Books Ltd.

Foster, George McClelland. 1973. Traditional Societies and Technological Change. New York: Harper \& Row.

Gifford, Paul. 1998. African Christianity: Its Public Role. London: Hurst \& Co.

Gifford, Paul. 2004. Ghana's New Christianity: Pentecostalism in a Globalizing African Economy. Bloomington \& Indianapolis: Indiana University Press.

Hollenweger, Walter J. 1972. The Pentecostals. London: SCM Press.

Jenkins, Philip. 2007. The Next Christendom: The Coming of Global Christianity. Oxford: Oxford University Press.

Johnson, Todd M., Gina A. Zurlo, Albert W. Hickman, and Peter F. Crossing. 2018. 'Christianity 2018: More African Christians and Counting Martyrs.' International Bulletin of Missionary Research 42, no. 1: 20-28.

Leonard, Christine. 1989. A Giant in Ghana. Chichester: New Wine Ministry.

Myers, Bryant L. 1999. Walking with the Poor: Principles and Practices of Transformational Development. Maryknoll, NY: Orbis Books.

Myers, Bryant L., ed. 2011. Working with the Poor: New Insights and Learnings from Development Practices. Monrovia, CA: World Vision.

Onyinah, Opoku. 2016. 'Pentecostal Transformation in Africa: The Rise and Growth of the Church of Pentecost.' Pentecost Journal of Theology and Mission 1, no. 1: 12-35.

Rostow, Walt Whitman. 1990. The Stages of Economic Growth: A Non-Communist Manifesto. 3rd edition. Cambridge: Cambridge University Press.

Weber, Max. 1976. Protestant Ethic and the Spirit of Capitalism. Sydney \& Boston: George Allen \& Unwin. 


\section{Internet and newspaper sources}

Daily Graphic. 'Recruitment of domestic servants to work in Gulf States suspended.' Thursday 1 June, 2017.

UNHCR. 2017. 'Global Trends: Forced Displacement in 2016.' www.unhcr.org/5943e8a34. www.globalissues.org/Geopolitics/Africa www.globalissues.org/issue/83/conflicts-in-africa www.cfr.org/africa/africas-conflict-zones/p14543

www.moibrahimfoundation.org/en 